\title{
Responsibility in discourse: Evidence, report and entitlement to speak in the Book of deeds of King James
}

\author{
J O A N A A R G E N T E R \\ General Linguistics \\ Edifici B \\ Universitat Autònoma de Barcelona \\ E-08193 Cerdanyola, Spain \\ joan.argenter@uab.es
}

\section{A B S T R A C T}

An ethnographic approach to language aims at explaining the organization of a verbal culture, understood as the result of speakers' practices and agency. The instrument of this research is fieldwork. For the verbal cultures of bygone societies, only examination of written records helps us to guess how speaking worked at the time. This general issue is addressed by scrutinizing a medieval Catalan chronicle. Ethnographic and pragmatic concepts are projected backward on data informative on face-to-face communication and the interactional construction of a social order. Speakers' rights and obligations, their metalinguistic and metapragmatic management of verbal resources (genres, texts, codeswitching), and the link between linguistic management and ideologies are uncovered. The article focuses on the relationship among evidence, knowledge and reporting of events, and the production and reproduction of authority in Catalan medieval society, as well as the different types of responsibility in discourse and their patterns of social distribution. Concentration is on three types of discourse events: delegated discourse, mediated communication, and a specific type of codeswitching in political oratory, quotation cum auctoritate. (Agency and discourse, power and authority, historical ethnopragmatics, verbal culture, codes and code-switching, Catalan)*

\section{N T R O D U C T I O N}

The ethnographer's first research instrument is fieldwork. Nevertheless, when ethnographers focus on verbal cultures and face-to-face communication in past times and are concerned with how these things worked in communities long ago, what the living flow of speaking was like and what effects it produced, what were the ways of speaking, the genres, the speech acts and events, how the people managed their verbal resources, moods of interaction, and politics of language - that is, when scholars deal with historical ethnography and ethnopragmatics - they are compelled to share the historian's, philologist's, and lit- 
erary scholar's knowledge and skills, since their source of evidence cannot be other than written texts.

Malinowski 1923 opposed philological and ethnographic research on language and communication. His assessment must be understood in its context and in relation to his idea of what philology was all about. His main argument was based on the opposition between the study of "dead" vs. "spoken" languages, of written text vs. living, situated communication. To begin with, I know of no natural human language that was never an oral language. In this article, Malinowski seems not to be acquainted with the development of modern linguistics at the time. As a matter of principle, at least, this addressed oral language. Moreover, asserting when a language should be considered "dead" is a question on the current agenda of linguistics and anthropology. ${ }^{1}$ Malinowski's concern, however, was the production of meaning in so-called primitive languages - a term that scholars at the time were trying to expel from the vocabulary of linguistics: let us, then, understand it as a metonym. Alternatively, his view on linguistic meaning was a pragmatic one avant la lettre - that is, indexical meaning, since it linked language forms to the context in which they occur, understood both as the cultural background and as the communicative situation frame. All in all, Malinowski was right to disregard philology - and linguistics - inasmuch as he highlighted human action and situated discourse in a cultural context. Ethnography was a much better approach to opt for. The question to be posed here, however, is whether ancient communities, including those speaking now "dead" (or just "old") languages, developed a particular organization of verbal culture meriting our interest, and whether this is an accessible object of knowledge, even if in an imperfect form - much as the reconstruction of a protolanguage imperfectly tells us something relevant about the structure of a language people spoke millennia ago, or the comparative analysis of formulaic expressions somehow reveals "some of the things they talked about, and some of the ways they talked about them in their traditional poetry" (Watkins 1981:773).

Of course, current life and historical sources - oral and written discourse ought not to be confused, and one must not be taken for the other. Occasionally, however, written records hint at bits and pieces of life-immersed speaking from the distant past (Argenter 2005a). Research on the verbal past offers not a transient object, as is the case in current fieldwork, but a bygone people's vanished talk in a lost-for-ever social context. Researchers, then, have to rely on documents to retrieve this talk and context and to explain the sense its inhabitants made of them, but they cannot elucidate that sense with the inhabitants' fresh information and knowledge, nor can they go back to reexamine speaking practices or to contrast their interpretations (Argenter 2001). Nevertheless, "the "world out there' ... often gives the distinct impression of active persons" (Pálsson 1995:81). That is, even if there is no present space for fieldwork, agency and life are still there to be grasped. 
Assuming the meaningfulness of such a purpose, in this article I study aspects of the verbal culture of a medieval society, to the extent that these may be extrapolated from written records, specifically from a medieval Catalan chronicle. Note that the historical ethnographer of communication is not confronted with "historical truth" but with a (plausible) way speaking worked in a social context at a real time. Pálsson, who regards the Icelandic sagas as "fieldnotes," states:

Even if the events do not occur as written, nonetheless the assumptions of how the social context ought to work (how it is represented) is reflective of the writer's own history and reality. Every saga contains echoes from a distant discourse.... If the factual and the fictive go hand in hand and any text or utterance is necessarily a collaboration of generations of writers and speakers, the boundary between literary studies and linguistics, on the one hand, and anthropology and history, on the other, is not as important as is often implied. (1995:85)

I am concerned here not with the "events" narrated in the chronicle as evidence for historiography, but with certain reported "speech events" that are informative on the interactional construction of a social order. The general issue I address is the possibility of using the Catalan chronicles as a source of data to uncover features of a verbal culture, including speakers' rights and obligations, their metalinguistic and metapragmatic management of verbal resources, and the link between this management and ideologies - in a word, speakers' practices and agency. I specifically address the relationship among evidence, knowledge and reporting of events, and the production and reproduction of authority in Catalan medieval society, as well as types of responsibility in discourse and their patterns of social distribution. One type of responsibility has its source in the speakers' participant-frame roles. Other types originate either from social roles or from the manipulation of codes and rhetorical resources in public performance. I concentrate on three types of discourse events/resources: delegated discourse, mediated communication, and a highly specific type of codeswitching embedded in political oratory - quotation cum auctoritate. These may be reduced to "talking on behalf of" and "quoting to the benefit of" speech event types. In addition, these are cases of communication in public arena, which in fact is the usual scenario in my source data.

T H E BOOK OF DEEDS OF KING JAMES

Medieval European chronicles are a well-known institutionalized written literary genre whose aim was to record selectively the achievements and the events that occurred during a king's reign. Often these texts were cultural and political products that emanated from the royal chancellery and were written down by 
illustrious men, usually officials, clergymen, or scribes whose skills in reading and writing gave them key positions in the higher ranks of society.

The functional antecedent of this written genre was the oral epic, composed to be either sung or recited. Occasionally fragments of these long poems were written down later - often as a performer's auxiliary technique rather than an intended literary work - and these texts became immediate sources for the chronicles. In this process, verse compositions were partially converted into prose. ${ }^{2}$

The Libre dels feyts del rei En Jaume (Book of deeds of King James), ${ }^{3}$ commonly known as the Crònica de Jaume I (Chronicle of James I), was written around 1274, though our knowledge of it is largely based on a later copy of 1343 , usually referred to as "the manuscript from Poblet," the monastery in whose scriptorium it was copied. ${ }^{4}$ The Book narrates the life and deeds of James the Conqueror, ${ }^{5}$ king of Catalonia-Aragon, Majorca and Valencia, count of Barcelona and Urgell, and lord of Montpellier (born at Montpellier, 1208; died at Valencia, 1276). The king himself is alleged to be the author of the Book, ${ }^{6}$ and the narrative is written in the first person plural of royalty. ${ }^{7}$ This feature alone discursively indexes a monologic narrative (Bakhtin 1981).

The implication that the king himself was the author of the Book merits an explanation. Philological internal evidence in the Book evidences a mixture of styles and registers, which usually has been interpreted as reflecting coauthorship by one or more chancellery officials - or, more probably, a clergyman - and the king himself. It is recognized, moreover, that the time gap between the original text and our oldest copy partially accounts for the co-occurrence of linguistic features from two language states, an earlier one corresponding to composition, and a later one corresponding to copying. An alternative view attributes the mixture of curial prose and fresh narrative - including dialogues, proverbs, codeswitching, and so forth - to oral production of the text, which would have been dictated by James at different periods of his life, helped by different scribes/ coauthors. The Castilian king Alfonso x, James's son-in-law and himself the author of a Castilian chronicle, wrote: "[T]he king makes a book, not because he writes it with his hands, but because he composes its subject matter, and corrects, rectifies and improves it, and he shows how must this be done, and thus this is written by he who is ordered by the king, but for this reason we say that the king makes the book." 8 A split responsibility for a written narrative was clear to the "author" - though it needed to be explained to his contemporary audience.

Nonetheless, the Book of Deeds partakes of a memoir-like character. The double role of the king as both the hero and the author, and his personal involvement in the narrated events, confer on the Book a subjective quality. A sense of modernity emanates from the Book because it narrates recent events rather than a distant past. This might have been the reason why its content aroused the curiosity and interest of ordinary people. Indeed, the Book was destined to be either read privately or listened to by a reader's audience (Riquer 1964:399). ${ }^{9}$ Thus, we 
read in it, "And so that those who SEE this book may know how many regions there are in Majorca" (72:1-2; Smith \& Buffery 2003:96), as well as "And so that those who HEAR this book may know what happened at Majorca was a singular deed of arms, we will tell you another example" (69:49-51; Smith \& Buffery 2003:94; emphasis added). ${ }^{10}$

Furthermore, the Book has a dramatic dimension because of the great number of dialogues it contains preceding and following action, in such a way that they eventually appear to be either a forecast or a consequence of the events. This crucial use of dialogue - represented face-to-face verbal interaction - opens a window into features of the verbal culture of the time and these features' social meaning.

\section{SOURCES OF EVIDENCE AND ITS CODIFICATION IN LANGUAGE}

In the analysis of the relationship among evidence, knowledge, and reporting of events in language, it is relevant to uncover how the experience and awareness of facts are linguistically codified and what the culturally recognized sources of evidence are. The analysis of the raw material dealt with here "takes into account three events - a narrated event, a speech event, and a narrated speech event ... namely the alleged source of information about a narrated event," in Jakobson's (1957 [1971]:135) statement of what "evidentials," as a verbal category, codify. To our purpose, this description holds even though evidentials are lacking as overt morphological categories in Catalan, where their functions are taken on by syntactic or discursive means.

In addition, the range of "alleged sources of information" that are explicitly acknowledged - that is, the forms of the verbal expression of knowledge and evidence - are not necessarily the same in all languages and verbal cultures: they may include direct experience from the senses (seeing, hearing, etc.), report by another person, hearsay, quotation, dream, supernatural inspiration, and so on. Sources of evidence, moreover, entail specific qualitative and quantitative support to competing arguments in controversial discourse, for example in the negotiation of political advantage. In fact, they do not equally authorize political discourses. The "politics of evidence" aims at selecting sources able to maximize authority and power in discourse. Let us consider an instance from the Book that will lead us to pose relevant questions in a natural way.

There is a case in the Book in which evidence is based on dream and vision (chapter 389). A friar reports another friar's dream vision: An angel of the Lord appeared to him and announced that a king was about to come who would prevent the Christians from being overcome by the Muslims in Spain. This is "the king of Aragon whose name is James." Two circumstances countenance this evidence: (i) the dreamer was a friar from Navarra, and thus apparently unconcerned about James's intentions (actually, he was disappointed because the king referred to by the angel was not his country's king); and (ii) he had revealed his 
dream vision in confession, and thus in a trustworthy speech act. Both factors allegedly strengthen the reliability of the story. To gain reliability was extremely relevant, since the dream story was brought up to lend support to King James's argument with the Aragonese noblemen to get their help in a military campaign to support the king of Castile against the Muslims. While King James's reasoning appeals, as a matter of principle, to their lord-vassal relationship, and in a very pragmatic way to cost-benefit considerations as well as military and political strategy, ${ }^{11}$ the churchman's argument appeals straightforwardly to a suprarational and close-to-sacred source - an angel is after all a messenger of God, hence God's voice, and this voice justifies King James's intention and argument. Moreover, confession itself is another source of evidence alongside dreaming, vision, or report. While dream and vision, then, was the dreamer-friar's source of knowledge, confession was the reporter-friar's. Additionally, the latter's report was the source of evidence for the Aragonese noblemen. Finally, the author's narrative in the Book is the source of evidence supporting the whole story for the reader, medieval or modern, ${ }^{12}$ though this narrative is not properly speaking a "speech event."

The reported dream, however, is not just a source of evidence. It legitimizes a political choice in a political discourse. We are faced here with the politics of dreams and the politics in dreams, dealt with by Friedrich 1986, for whom "it is the underlying relations of power that organize and drive the dreams." The dream reported is a political dream, since its content is political - it is a dream about war, ethnic conflict, and power - and so is its interpretation and use, since it becomes "the input to politics: as the basis for motivation in leaders ... or as part of political speech." In summary, the friar's dream is reported precisely because allegedly it has the force to cause others to take up, induce, or justify specific political acts and strategies - not general principles. Biblical tradition, indeed, held dreams to be "a subfield of the art of government" (Friedrich 1986:81-82). To historical ethnography, the relevant point is that reporting a dream in order to strengthen someone's argument or to reinforce someone's authority appears to be within the logical, social, and pragmatic order of things at the time - as it is in certain communities today. ${ }^{13}$

Some interesting questions may be raised at this point: Who was entitled to argue on the matter at hand? What kind of evidence or reasoning was relevant to be adduced, and by whom? Could this evidence and these reasons be challenged by the audience, and to what extent? If so, whose evidence and reasons could be challenged? Was anybody entitled to report another's talk? If so, under what conditions? Although I will not respond to these specific questions here, I will address similar ones.

This piece of verbal interaction, the conflict between James and the Aragonese noblemen, speaks of a particular relationship in the power structure of the Arago-Catalan polity at that time, hence the underlying historical logic of the event. The political relationship between the two territories was a confederation: 
each one had its own laws and customs and was ruled according to them. They had a common ruler, though. Partly because of the feudal structure prevailing in Aragon as against an emerging urban mercantile society in Catalonia, the Aragonese noblemen saw the king not as a monarch but rather as a war leader, eventually "one of us." James's difficult relationship with the noblemen and knights led him to rely on the emerging Catalan bourgeoisie and the region's Jews to strengthen his power and authority.

ASSUMING COLLECTIVE RESPONSIBILITY: THE CASE OF

DELEGATED DISCOURSE

In this section I consider what I term "delegated discourse": discourse in which an individual speaker assumes the re-presentation of a collective actor, whether he is an informally designated spokesman or a formal spokesman of a group of people whose statement has been previously agreed on. These roles are exemplified in excerpts (1) and (2), respectively. In both cases, co-presence of re-presenter and re-presented is implied. The first comes from the chapter in which the king learns of Sir Bernat Guillem d'Entença's death ${ }^{14}$ :

(1) They all came before me grief-stricken; and all the nobles said to Don Ferdinand ${ }^{15}$ that he should show us the message and inform us of the death of Don Bernat Guillem. ${ }^{16}$ And we knew from their faces that they had received terrible news.... And afterwards Don Ferdinand began to speak, for himself and for the others, and he spoke in this manner: "My lord, Our Lord has made all the things in the world, and He undoes them when it pleases Him. Now, we are obliged to do anything that may be to your profit, and that would please us greatly; whilst we would lament any misfortune that were to befall you. For we have received some news through which you could suffer harm, unless you take counsel on it rapidly. And we are greatly saddened by the news, both for him, who was so worthy, and for you: for we have to inform you that Don Bernat Guillem d'Entença is dead; and we know this for certain. Moreover, as he held so great and honourable a position through you, on the frontier, it is important that you take counsel." (231: 7-23; Smith \& Buffery 2003:202-3) ${ }^{17}$

Although these noblemen are all bearers of the sad news, they designate Don Ferdinand to be the spokesman on this unfortunate occasion: He is appointed as the man who will "show the message," and he is indeed the one who begins to speak, on the understanding that he presumes to speak "for himself and for the others." Precisely because of this, "delegated discourse" cannot be equated with "surrogated discourse" in the sense of Yankah 1995. Surrogated discourse is defined as "the exercise of performance through an agent, instrument or intermediary" (i.e. "performance for or on behalf of another") and is occasionally referred to as "delegated discourse." This resembles the case in our material, but the "representers" in Yankah's study do not talk on behalf of themselves. In contrast, in (1) the speaker re-presents not "another" but "others," and the individual representer is included among the collective re-presented. Moreover, co-presence of re-presenter and re-presented is implied. There is a distribution of discursive responsibilities, but these appear to be interactionally rather than socially constituted, even though social status is not completely absent. Nonetheless, "del- 
egated discourse" implies, as "surrogated performance" does, an engagement in the art of public display and verbal indirectness.

In terms of the participation frame and the analytic decomposition of participants in socio-communicative roles, Don Ferdinand becomes both the "animator" and the "author" of the discourse, but he is not its "principal" (Goffman 1981). Don Ferdinand's discourse begins with a sententious expression whose source is to be found in the Bible, the liturgy, or homiletics, and he introduces a codeswitch, whose limits are at the beginning and the end of the sentence ${ }^{18}$ : "Our Lord has made all the things in the world, and He undoes them when it pleases Him." The king has guessed by the look of the noblemen "that they had received terrible news." Don Ferdinand's words ratify this premonition. He bases his message on the fact that "we have received some news." These words attempt both to mitigate the responsibility for the information - whose source is hearsay, hence a distributed and unsure knowledge - and to mitigate the communication of bad news by delaying its delivery. ${ }^{19}$ It is a persistent discursive strategy in similar communicative contexts - namely, bad news communication, a particular verbal genre.

From the narrator's perspective, either the notification of a mournful event or a detailed description of the nobleman's death are beside the point. In fact, the chapter begins with this sentence: "When we had been at Zaragoza for eight days or more, a message reached us saying that Don Bernat Guillem d'Entença was dead" 20 (231:1-2; Smith \& Buffery 2003:202), and indeed it could have been finished at this point. ${ }^{21}$ What actually is at stake is the way in which the business will be explained to the king.

From the participants' perspective, on the other hand, the issue is neither the bare notification nor an accurate relating of an experience close to the fact, since both would presuppose the noblemen's having witnessed the death, which they did not. Rather, they only "heard some news" - a hearsay experience. What is at stake is who is going to be (i) entitled to reproduce these facts verbally, (ii) designated to talk on behalf of the others, (iii) able to manage a specific verbal genre, (iv) authorized to address the king, and (v) successful in adequately exercising these responsibilities, as well as (vi) performing well verbally. Don Ferdinand's discourse implies that felicity conditions (i)-(iv) are met. As a matter of fact, Don Ferdinand will be held responsible not only for his performative act and his preface, but also for his discourse's perlocutionary effect, since the point is indeed a political and strategic one. ${ }^{22}$ Bernat Guillem's death is, of course, a mournful event, but first and foremost it turns out to be a matter of war politics. Don Ferdinand, himself a counselor, twice urges the king to take counsel on it. Mitigation and delay do not bar pressure on political urgency. Entitlement to speak is related to procedures of representation, designation, and identification of interlocutors, but also to the distribution of knowledge, rights, and obligations within society.

The second case of delegated discourse appears when this responds to a demand by the king, when he asks for counsel. The answer arises from a formal 
agreement-building process and a formal designation of the re-presenter by the represented. Moreover, it also implies a different speech act event, as we see in excerpt (2):

(2) So they deliberated, and when they returned to our presence, Don Ferdinand explained, on behalf of all the others, what they had agreed. And he said: "Lord, in this matter that you speak of, we see a great difficulty, for reasons we shall now explain. Because it would not be fitting for you to begin an enterprise and not complete it, and in the entire army there is not food for five days. Moreover, Valencia is not yours but rather is held by the Saracens. (195:3-9; Smith \& Buffery 2003:179) $)^{23}$

In this case, Don Ferdinand has been urged to be the first to speak. He asks for consultation with the other noblemen before speaking, in order to reach mutual agreement. Only after the noblemen, gathered in council, agree about what they would answer to the king (i.e. what advice they were about to give him) does Don Ferdinand take his turn and participate in the communicative event by delegation: He expresses "what they had agreed." Even though the responsibility for the content of the advice is collective, it is incumbent upon Don Ferdinand to speak before the king; then he is also accountable for overt and fair performance before both the source and the target participants (Bauman 2004:131-33), ${ }^{24}$ as well as for the effectiveness of his speech. His entitlement to speak derives both from the counselors' delegation and from his role and position as a previously ratified participant, and it emerges in ongoing verbal interaction. The procedure that creates entitlement to speak is more formal and complex than in excerpt (1), in which there is nothing to agree about.

Whereas in (1) an item of factual information is transmitted that is not at all controversial, in (2) an item of advice is transmitted that may be subject to debate and may be accepted or rejected by the royal authority. ${ }^{25}$ Note that the speaker in (1) and (2) is the same person, a relative and counselor of King James. However, the illocutionary force of both discourses is not the same, inasmuch as the speech acts are different too: a declarative (informative) vs. an advice. Nonetheless, formal indirectness characterizes both. Obviously, the speaker's attitude toward the discursive propositional contents is identical. Different epistemic and pragmatic conditions of discourse then affect the responsibility that is assumed by the actors in speaking. After all, Don Ferdinand is playing his role as a spokesman and re-presenter of the noblemen. Another sociopragmatic factor, however, is to be taken into account: the hierarchical or interpersonal relations among participants in the communicative event - certainly not a negligible factor, as will now be shown.

MEDIATED COMMUNICATION: SOCIAL HIERARCHY, ENTITLEMENT TO SPEAK AND EFFICACY OF DISCOURSE

In what follows, we examine a passage in the Book that will permit us to identify how pragmatic and social structure combine in speaking events. This passage (chapters 518-519) describes the king's intention to make peace with his son, 
Prince Peter, with whom he fell out because the prince had publicly insulted his own half-brother, Ferran Sanxeç. The king sends as messengers to the prince men from his court: noblemen, an archbishop, other bishops, and knights. They fail to accomplish their mission twice.

After their first failure, the king gathers the messengers to agree on a strategy. In this meeting, the archbishop explains the discussion they held with the prince. Disappointed in them, the king dictates the words that are to be transmitted to the prince, and he emphasizes these words carefully: He writes the script and emerges as the "principal" - even the "author" - of the message (ex. 3). The messengers will be its "animators." Seemingly, then, the king questions his messengers' previous "copy" of his first "original." The asymmetry of their rank relationship with the king demanded a rather strict replication of his words (Urban 1996).

(3) And the archbishop explained to us the discussion that he had held with him. But we said to them that they should not have proceeded in that way, between us and him, rather that he, who was an archbishop, and the bishops and the nobles, and the citizens who were there, ought to say to him: "Why have you fallen out with your father? For he says to you that if he has wronged you, he will repair that, to your satisfaction. And if you do not wish to do so, we must inform you that you shall lose us and all the kingdom and we will go against you, as one who is a rebel against his father."

And if you had said that, he would not dare to have departed without abandoning his opposition to me. And how could you leave here, where you are gathered together, without making any progress against so great an evil as there is between him and us? When you meet anybody on the road, and he asks you how it is that you have left the King and his son at war and in conflict, you will have to turn away as miserable wretches. (518: 5-17; Smith \& Buffery 2003:355) ${ }^{26}$

King James manages to control the speech event completely, and he nuances his discourse by means of a singular display of metapragmatic regimes and personal deictics, entering into and exiting from the discourse at his will. The king's script is contained inside the king's reported speech, which is contained inside the king's narrative. Note that the king's script is highlighted by a shift in metapragmatic regime from indirect narrative (we [King James] said to them [the messengers] that ...) to direct reported speech (he [the messenger archbishop] ... ought to say to him [the prince]: "Why...). This shift underlines the king-asnarrator's freedom to make a non-verbatim report in the narrative, in contrast to the mediator's commitment to verbatim replication of the king-as-protagonist's (the speaker's) original. James's reported script, though immediately regimented by his own speech and ultimately regimented by his narrative, is anchored both in the "source dialogue" - insofar as it is framed as direct discourse addressed to the messenger(s) - and in the "target dialogue," insofar as a sudden shift in personal deictics frames it as if it were a nonmediated source-target dialogue (we [the messenger(s)] must inform you [Prince Peter] that you shall lose us [King James] and all the kingdom and we [King James] will go against you, as one who ...). That is, the source dialogue splits into two dialogue participant frames in an exercise of reflexive intertextuality. ${ }^{27}$ The split of participant frames un- 
derscores to what extent the mediators substitute for the source speaker. After relaying his script, the king returns to the earlier deictic structure (... if you [the messengers] had said that, he [Prince Peter] would not dare to have departed without abandoning his opposition to me ...).

The noblemen agree to go to the prince again. When they are face to face with the prince, a scene takes place that is not uncommon in the chronicle, but in this case all its meaning, force, and consequences are displayed. The incident has to do with the management and distribution of responsibility in language:

(4) When they arrived there, they said to the archbishop that he should explain the matter on behalf of them all, and he said that he would not do so. And they said to the bishop of Barcelona and to the other nobles that they should say it, and nobody wished to do it. Then they said to Juan Gil that he should speak on behalf of them all; and Juan Gil said: "And how should I explain this business, when an archbishop, bishops, and the nobles are here? How should I do it?"

And all said that they wished him to explain it. Then he raised his hands towards Our Lord and said: "I thank God that they have entrusted me to explain the business; and may God will that I can explain it in such a manner that may be to the honour of the King and the profit of the prince."

And he explained the matter, but neither as fully nor as forthrightly as we had told them to. And afterwards they returned to us and told us that they could not resolve it. And they told us what the prince wished to do, and that he would do something to our injury, but we did not wish to believe it. Then the nobles said that as they were unable to resolve anything and had already spent what they had, they would go from there. And we said: "Now go, and bad luck go with you, as we will finish what we had asked well enough without you." And so they left. (519; Smith \& Buffery 2003:355-56) ${ }^{28}$

Obviously, communication through messengers was usual at the time; often, however, their role was not just that of message-bearers but also of mediators. To know how to "pass the word" was, then, extremely important. Mediated discourse was not only a way of overcoming distance between the addresser and the addressee of the message. It was also a way of exerting authority, at the same time concealing and indirectly manifesting it through substitutes who were invested with authority to display its performance in the absence of the king. This case is closer to surrogated performance: The mediator is responsible for the performance, not for the message itself. For this very reason, to refuse the messengers'/mediators' word is to refuse the king's word, hence a challenge to his power. The messengers/mediators interpose between the royal addresser and his addressee, thus protecting the king's public image from being diminished.

A similar observation on the manifestation of power in "absence" was made by B. R. Anderson, as reported by Errington in his study of Javanese Indonesian communities:

Anderson (1972) has drawn on Javanese historiographic tradition to characterize this "higher power" as being evident, so to speak, only in its absence. Paradigmatic in this regard is the image of an unmoved, unmoving king, whose oversight and will is manifested only mediately, beyond the more obvious ambit of his detached seclusion. By this political cultural logic, Anderson sug- 
gests, the locus and nature of power can be known only as it is indirectly manifested through its delegates, not directly from its source. (Errington 1998:70)

I do not intend to suggest that medieval Catalan kingship was such a hieratic institution. It was not, but doubtless certain resemblances are apparent.

In our case, the messengers were ad hoc spokesmen. They were not permanent officials in the way spokesmen are in some other cultures. However, in this case we are closer to "surrogated discourse," since they only talk on behalf of the king, not on their own behalf, as is the case in "delegated discourse."

Turning to excerpt (4), we observe there a downward displacement of responsibility for discourse, to the extent that the request "to explain the matter on behalf of them all" is successively refused by the actors implied and transferred downward from one grade to the next until the responsibility falls on the lowest level of hierarchy: Juan Gil, a citizen who held the position of magistrate at the time (Soldevila 1971b:388). Since this hierarchy is not one of command but of dignity, hence a hierarchy of responsibility in the ordered commission and of entitlement to speak appropriately and effectively on behalf of the king before Prince Peter, Juan Gil objects to the inappropriateness of the decision - after all, he is not a nobleman. However, since the hierarchy in dignity is an inherently authoritative hierarchy too, he is compelled to talk, "to explain the business." His first words are illustrative of his perceived situation as a speaker who is essentially nonratified, except in that he has been appointed. Consequently, he begins his speech according to a formalized discursive pattern combining the "removal of guilt" (Bloch 1975:7) or apology for his self-assertion as a speaker in the occasion, thanks to God for the opportunity to speak, and a prayer for the success of his endeavor.

He becomes, then, the "animator" of the word to be spoken - and somehow its "author" too, since he was not present in the meeting with the king. He "passes the word," but, alas, "neither as fully nor as forthrightly as we had told them to." Juan Gil's word has not been effective. Is this a matter of communicative skill, or a matter of entitlement to the use of the word? One might guess that the latter rather than the former is true - so much so that, not much later, the commission is accomplished by the bishop of Valencia.

Why did Juan Gil fail in his intent? Two conditions seem to be at play in this failure. In the first place, talking on behalf of another in mediated communication is a speech event that implies a previous speech event; that is, the re-presenter and the represented must have been direct participants in a communicative event as addressee and addresser, respectively. The goal of this speech event is not just to transfer the message, but to ratify the messenger. As noted, Juan Gil did not attend the meeting between the king, the clergymen, and the noblemen. Hence, he was not an entitled messenger. Second, his low hierarchical position was not optimal for him to talk on behalf of the king, and his voice 
was the one most easily challenged by the prince. Hence, he was not an entitled mediator. Nonentitled persons are not accountable for the efficacy of their discourse.

There is something more at stake in this event than mere entitlement to speak or feudal rank hierarchy. To understand the whole sequence of elementary speech events co-occurring in it, we need to account for the entitled persons' right to refuse performance and to transfer responsibility without transferring authority. These refusals, transfers, and retentions of different kinds of responsibility from the top down illustrate how this critical speaking event does not just "reflect" social order but turns out to be "a key site for the production and reproduction of rank and dignity," in Hill \& Irvine's (1993a) words. Though social order in medieval times was tightly and statically organized, it must be assumed that particular speaking events were a privileged means by which this order was socially constructed and reproduced over generations and a person's lifespan. In her study on Wolof greeting, Irvine remarks that "any two persons who engage in an encounter MUST place themselves in an unequal ranking." The conclusion is that "the mere fact of initiating a greeting is itself a statement of relative status" (1974:173-75). Speaking does not only "reflect" social structure, it actually "creates" it.

The institutional distribution of political power in medieval Catalonia has been described as pactisme 'agreement-reaching' (Vicens Vives 1954, Batlle 1988, Vilar 1988). By this is meant a regime based on formal agreements between the king and the noblemen first, but thereafter also involving the churchmen and the free citizens or new urban elites. These are the three estates represented in the cort, an assembly in which matters of government were dealt with, an emerging political institution of the kingdom side by side the king's council of advisers. The latter reminds us of a cabinet, and the former to some extent of a parliament. This institutional system became consolidated during James's reign.

Political institutions mirrored societal structure and hierarchy. Passing speech responsibility downward in the reported event in (4) mirrors the societal and political structure, hence reproducing authority and power.

PAT TERNS OF DISTRIBUTION OF RESPONSIBILITY

This distribution of responsibility to third persons occurs in many cultures, and it often follows a similar downward pattern leading from more powerful to less powerful persons. That is, the performance of responsibility percolates from the top down.

This is supported by a number of ethnographic studies. Hill \& Irvine (1993a:21) summarize some well-known cases. Among the Wolof in Senegal, griots (praisesingers) used to belong to lower castes and performed on a salaried basis for socially higher-ranked people (Irvine 1974). Among the inhabitants of Samoa, during the fono - a particular communicative act studied by Duranti 1981 - the 
tulafale ("orators" or "talking chiefs"), lower-caste men, not only represent their patrons in ritual ceremonies but also perform as spokesmen when it is necessary to defend controversial views (Duranti 1993). Among the Kuna in Panama, chiefs speak in an elevated register that the common people no longer understand, and a lower-ranking official translates it into common language (Sherzer 1983). One may add the evidence adduced by Errington 1998 from Javanese communities: In certain ceremonies, ritual spokespersons "re-present and ventriloquate" their inactive ritual sponsors' interests. In this case, as with the Kuna, levels of language are involved (exemplary Javanese, or básá, is a refined speech variety used by these spokespersons). Among Akan communities in Ghana the akyeame, or chiefs' verbal mediator officials, are "masters of the spoken word" and "lords of diplomacy" (Yankah 1995). This pattern of downward transfer of responsibility seems to be universal, albeit differing in form, and still may be observed in modern societies.

While the exercise of responsibility, then, is transferred to individuals of lower rank, actual authority and the right to blame these individuals are retained by the higher ranks. ${ }^{29}$ Indeed, in these cultures it also is observed that, though the lowerranked person speaks on behalf of the higher-ranked, he may be blamed if the outcome of his performance is not successful. As Hill \& Irvine 1993a remark, the rationale behind this social behavior pattern is that the person lower on the social scale "has nothing to lose" or, at least, that it would be worse for the community to let someone undermine the authority or threaten the face of the person of higher social rank. Moreover, Duranti 1993 suggests that one of the reasons for this socio-communicative pattern is to allow the higher-ranked person to change his mind without loss of face.

\section{CODESWITCHING “CUM AUCTORITATE”}

Excerpt (5) reproduces the entirety of chapter 527 in the Book. It reports the discourse that King James engaged in before Pope Gregory $\mathrm{x}$ and his cardinals gathered at the second council of Lyon (1274). By then James was 66 years old, but even so, he was willing to participate in a newly launched crusade, after he had failed in two earlier enterprises, because he was eager to improve his political relations with Rome - the Roman Church had been supporting French political interests against those of the Arago-Catalan crown. James also failed in his aim to be crowned king by Pope Gregory. However, he participated in the council and delivered his speech, a masterpiece of political oratory:

(5) Then we got to our feet and went to take our hat from our head. And the pope said we should not do that, but we should sit down and put our hat back on our head. And the cardinals, all with one voice, said the same thing.

When we had sat down, we said to him he had sent us a message asking us to come there on the day of the council. And that later he had sent us a preacher by the name Fra Pere d'Alcanar, who had brought us a letter saying that we should believe what he would say on his behalf. And we said to him that we would recall some words that Our Lord 
spoke in the Gospel: Gloriam meam alteri non dabo. ${ }^{\mathrm{a}}$

"Now, I say these words for this reason. Because I wanted to come to you and since you had sent me a message, I did not wish to disclose my intention to anyone but you. Moreover, it was not fitting that I should show my good intentions to your messenger, but rather it was necessary to show that to you personally and before whomsoever you might wish. We find in the Prophets, that is, in Isaiah, that on the feast of Our Lady Saint Mary, when she brought Our Lord to offer at the Temple, she said: Lumen ad revelationem gentium, ${ }^{\text {b }}$ which means to say 'The Light is revealed to all peoples'. And so it is true. For when He was born and Our Lady Saint Mary offered Him to the Temple, the Son of God was revealed to all peoples. For which reason, we can refer these words regarding this, your council, which will be good and holy, in likeness to those.

"Let what other popes could not do nor accomplish in recovering the Holy Land of Outremer, in which land God wished to die for us and be buried, now be accomplished through your words and your works, which you undertake with the clergy and the nobles. And let that light which could not shine fully until now, shine in your times, and be lit to you. Now, I have come here for the two things about which you sent to ask me, and a third of my own. The first is that you sent me for give you counsel; and the second, to give you help. I have come here to give you the best advice I can and know how to and that God will place in my thoughts; as well as to help you. The third reason is my own: because I will encourage those who have no desire to serve our Lord by taking part in this, and I will have so much to say and will do so much to achieve this, that they will be persuaded."

On hearing these words, the pope and the cardinals began to laugh because we had spoken so well. And we left them very content with us, and they thanked us very much for the words we had spoken to them. And then we returned to our lodgings. (chapter 527; Smith \& Buffery $360-61)^{30}$

Both James's behavior and speech are especially solemn, as the occasion demands. At the same time, his narrative underlines the formal treatment that the pope extended to him, also manifest in the preceding and following chapters. Let us consider now his speech in (5), specifically its two cases of codeswitching - a type that I conventionally term "codeswitching cum auctoritate." For the sake of convenience, I repeat them here:

(6a) And we said to him that we would recall some words that Our Lord spoke in the Gospel: Gloriam meam alteri non dabo.

(6b) We find in the Prophets, that is, in Isaiah, that on the feast of Our Lady Saint Mary, when she brought Our Lord to offer at the Temple, she said: Lumen ad revelationem gentium, which means 'The Light is revealed to all peoples'.

Catalan/Latin codeswitching is not unusual in formal speeches in the Book. Sometimes it responds to a type of codeswitching similar to doubling, in that it co-occurs with a translation into Catalan as in (6b), framed in either direct or indirect style within the speech. Translation, however, is not always compulsory, as shown in (6a). One may wonder, however, whether translation was part of the speech activity in $(6 b)$ - it surely was in other cases - or whether it was a later metanarrative comment by the king-as-author.

\footnotetext{
a Isaiah 42:8 ("My glory I give to no other").

${ }^{\mathrm{b}}$ Luke 2:32 (fulfilling the prophecy of Isaiah 42:6). The words in the Gospel are spoken not by Our Lady but rather by St. Simeon.
} 
Both cases of codeswitching in (5) are Latin quotations from the Bible embedded in reported speech. Four code features are evoked simultaneously: an authoritative holy source (vs. the speaker's word), a written text (vs. speech), Latin as a sacred language (vs. everyday Catalan), and a distant past (vs. here and now). Both quotations are "texts," understood as metadiscursive constructs, "meaningful building blocks of shared culture" (Silverstein \& Urban 1996a, Urban 1996), extracted from the repository of the community's verbal and ideological resources and actualized through social practices. They have been decontextualized from the original source and entextualized in the reported discourse (Bauman \& Briggs 1990). ${ }^{31}$ In the new context they dialogically acquire a new sense. As the reader can infer from the translators' notes (notes a and $b$ in the full excerpt), what is at stake is not the speaker's display of good knowledge of the scriptures - in fact, this knowledge is rather imperfect in terms of verbatim reproduction of the text, exact setting and participant-frame description, and source identification all at once (Pujol 2001).

Catalan scholars who have dealt with codeswitching in the Book analyze nearly all cases in it as "situational codeswitching," following Badia's (1987) early approach. Thus, in their view codeswitching in (5) would be triggered because of the pope's participant role as the addressee, or by the very presence of pope and cardinals in the communicational setting. I think this might not be the best of interpretations. Catalan/Latin codeswitching appears in several occasions in the Book, certainly for most of those involving churchmen in these settings, but this does not imply that these codeswitching tokens are presupposing rather than entailing contextual factors. One can plausibly hypothesize that they index the purpose of the particular ongoing speech and strengthen its argument; they are strategies of contextualization as much as they are anchored in a shared cultural, ideological background.

Latin quotations, then, are not only reported speech but also links in a complex, unfolding chain of reasoning. These quotations strengthen the force of conviction in speech. They are also "links" in a sense similar to that of the term as it is used in computer jargon, in that they activate a network of new references and voices; they open a window onto a new discourse and take the hearer to a new figured site. Moreover, they help to structure the discourse. This is patterned somehow according to the proposició, or "proposal," verbal genre or discourse type, that is, the king's opening verbal display at cort (Argenter 2005b). This was based on a twofold structure: The former part of the discourse was an extended, highly structured, rhetorical preamble containing considerations of good governance and appropriate behavior in the lord-vassals relationship, and was aimed at justifying the latter part, in which the matter in hand or the king's purpose was straightforwardly stated. Latin quotations were common in the former part, whereas the unfolding of a tripartite way of reasoning was common to either the latter part or to both. ${ }^{32}$ There is no surprise, then, in the way James ends his speech. 
Note that the important point in the first codeswitching case in (5) is James's justification for why he behaved as he did before Fra Pere d'Alcanar, the messenger who advanced to receive his response to the pope's call on his behalf. The crux of the matter is James's claim to keep his right to talk directly with the pope, since the latter had the king called to Lyon - hence James's dismissal of Fra Pere d'Alcanar's message. Rather than performing a disclaimer, James's metapragmatic management of his Latin quotation "My glory I give to no other" (Isaiah 42:8) is intended to enhance his position as a ratified speaker and his speech as grounded on scriptural teaching - though he mistakenly, so it seems, asserts that he is drawing it out of the well of the Gospel. ${ }^{33}$ By this move he partakes of shared uncontroversial traditional authority, retains his entitlement to speak before the pope without intermediaries, and enacts his speech. All these co-occur in ongoing conversation, starting with James's "procedural matter" petition and ensuing with his claim on the pope's commitment to listen to him before entering into the main matter - which James does immediately by codeswitching into Latin again, apparently referencing another scriptural quotation.

We come thus to the second codeswitching token, "The Light is revealed to all peoples." King James draws this dictum out of Isaiah 42:6 again, and he is to build his ongoing discourse on it; his metapragmatic assertion of the source is now correct, but his attribution of authorship is not. ${ }^{34}$ James builds up a chain of what we can construe as "figurae" in Auerbach's (1974) sense. This chain links Isaiah's prophecy in the Old Testament with Simeon's recognition and intertextual performance as reported in Luke's narrative of the presentation of Jesus of Nazareth in the temple. Thus the former is the figura of the latter, and in King James's speech the latter is turned into the figura of Gregory's Lyons II council, the proposed crusade, and its predicted success.

Auerbach's notion of figural interpretation (1970, 1974, 2003:73-76, 15662) relates two historical events in such a way that the first means both itself and the other, while the second resumes and fulfills the former. The two events are not related by a causal and chronological sequence; they are not contiguous along a "horizontal" axis of continuous historical development, but separated on its "vertical" axis and connected on the basis of abstract typological features, outside their synchronic relationship to other facts, and this makes them appear like a planned, unendingly iterated, self-responding event.

If we take account of the fact that both codeswitching tokens in (5) are cases of others' speech quotations, we can conclude that a close-knit relation, though not identity, may exist between figura and dialogism in them. Here figura emerges out of speech quotation rather than event description, but, even so, it continues to relate full historical events. I accept that the meaning in this case is closer to symbol or metaphor, as the speaker seems to imply, but the words transcend a dialogical linguistic or intertextual relationship and point toward historical events, partly real (the council), partly imagined (a successful crusade). It is this con- 
strual of the deep meaning of two events by means of each other that is proper to figural thinking as an overarching view of history.

A recent present event equals a distant past event, then, and this relationship makes sense of them in present life. This sense emerges by means of the scriptural quotation and its updated gloss. The speaker is not responsible for the propositional content of the original statement, but it is incumbent on him to recontextualize it in situated speech - that is, to ensure that the quotation is appropriate to the context, and the gloss to the quotation. What is at stake is faithfulness, or, in other terms, the politics of minimalizing the intertextual gap (Bauman \& Briggs 1992), while maximizing the coupling of text and current co(n)text.

Quotation from ancient speeches or dicta from scriptural sources, then, must be distinguished from everyday reported speech - as this appears in (1-4) aboveand it emerges as a salient feature in the construction of dialogical, authoritymaking formal discourse in the world the Book depicts. Intertextual relationships inhabit living discourse and are brought about by human agents in living discourse - not just by the analyst. ${ }^{35}$

Furthermore, the strategy underlying the Book may be described as a figural narrative too, in Auerbach's sense. This is clear from the very preface, certainly not a narrative genre. ${ }^{36}$ The "figura" pattern relating events from the Bible to James's life is continuous. James's deeds are justified because they are prefigured in the scriptures. This policy is intended to convince the listener/reader that James's will, deeds, and achievements accomplished God's design for the world. James was the chosen hero for the chosen goal. Just as the Old Testament prefigured the New Testament, so the latter prefigured James's deeds. It might appear as though this structure was intended to sacralize James's life, and eventually the institution of kingship. It need not to be so. Rather, the aim was both to justify James's expansionist politics and to write down a narrative that would be hard to challenge. Thus, what we saw above with respect to living discourse (on the Book's grounds) was transferred to the whole narrative. Its authority-making status was granted not only because it was produced by a king on earth, but also because it was legitimized by God. Strategies in the narrative are not that different from strategies in the narrated events. In the long run, oral represented agency and literary representing agency follow similar patterns.

The external context is not alien to all this. Besides the Church's pervasive influence and presence in medieval European society, the historical and everyday contexts in the Iberian local kingdoms were defined by religious contention between Christianity and Islam, ${ }^{37}$ and by the struggle - and coexistence - between Christians and Muslims. They were also characterized by a complex knot of dynamic back-and-forth relations among Christians, Muslims, and Jews living together (Argenter 2001). James's deeds would speak to his vassals and other (Christian or Muslim) kingdoms not only of his value and strength but also of his God's will and overpowering supremacy. 
Finally, the Book was written as a document to be left behind: It was James's legacy to his successors and people. It accomplishes a forward-looking function. The Book gives a past to future generations, a past on which to build their actions, a past on whose basis to "make a present," coherently with James's eagerness to enlarge the heritage he received from his forebears rather than just to preserve it. ${ }^{38}$

\section{O N C L U S I O N}

The intersection of language synchrony and diachrony defines a field in which phenomena prototypically belonging to either appear as belonging to both, and explanatory principles, prototypically elaborated for one axis, may be projected forward and/or backward from one axis to the other. Thus, the study of language structure benefits from our knowledge of previous stages of the language, and the study of linguistic change benefits from our knowledge of the mechanisms of ongoing linguistic change in synchrony. In the same vein, the study of bygone verbal cultures benefits from our knowledge of present-day verbal cultures. Here I understand "verbal culture" as the result of speakers" agency and communicative practices - either situated discourse or scriptural practices - a result shaped by both long-term established behavior and current choices in the face of new challenges and conflicts.

It has been my aim to show whether and how we can take advantage of our current ethnographic knowledge to illuminate aspects of ancient communities' verbal cultures, and to lend support to ethnographic theory from historical evidence by scrutinizing written records, identifying bits and pieces of actual communicative practices, and projecting on them an ethnopragmatic analysis. I have been concerned with the production and reproduction of authority in Catalan medieval society, closely knit with types of responsibility in discourse and their patterns of social distribution. Three types of discourse events have been considered: delegated discourse, mediated communication, and a highly specific type of codeswitching in formal language. All involve reported speech and may be reduced to the speech event types "talking on behalf of" and "quoting to the benefit of." In addition, these are set as public-arena events. Their relations to surrogated performance and other ethnographic concepts drawn from textual-, practice-, and agency-oriented approaches have been underlined. The proposed approach combines these concepts insofar as they refer to the result of speakers' metalinguistic and metapragmatic awareness and agency. Types of discursive responsibility and authority, as well as their social distribution, are governed by pragmatic conditions, interactional structure, social hierarchy, or skill in the management of verbal resources (e.g. texts, genres, codeswitching) - or a simultaneous combination of these. The mode of production of a royal chronicle and the relationship between this and (language) ideology has also been illustrated. 
Public discourse and delegated/mediated discourse played a crucial role in medieval society, as is clear from the Book of deeds of King James. However, not all discourses were equally effective in this context. Effectiveness emerges from different felicity conditions, particularly entitlement to speak, especially in mediated discourse - a salient feature in medieval verbal culture. Eventually, the consequences of discourse often are the social meaning of discourse. Behind entitlement to speech, commitment through the word, and the circulation of knowledge according to certain norms, the communicative patterns of responsibility-transfer and the management of textual resources, there emerges a linguistic ideology that has much more to do with what can be responsibly carried by one's word from one's own position in the world, than with what the word can represent symbolically. This word is not the written word, but the one declared orally in natural circumstances, whether in a solemn or a homely context. In verbal interaction, the written word always remains a pervasive and authorized reference, but a shadowy and distant one.

The analysis of the cases presented here shows the linguistic, discursive, and narrative resources that were mobilized in the assignment and the assumption of responsibility in discourse, and its social distribution. Also, particular textual and transtextual resources aiming at the appropriation of others' voices contribute to authority-making discourse. The analysis demonstrates the importance of these factors with respect to the maintenance of or challenge to the established social order in the world that the Book of deeds discloses to us, and eventually their interactional contribution to the production and reproduction of this order.

Despite the ethnographer's feeling about the failure of philology to give insight into the ultimately social grounds of the meaning-production process as a result of concerted human action, philology is not that distant from ethnography when the latter looks into the historical dimension of verbal culture and tries to uncover how speaking worked in a bygone time. Moreover, ethnography is not that distant from philology when the latter tries to understand how the represented world of written records relates to real life and life-immersed discourse. A historical-ethnographic approach to pragmatic meaning in human communication is indeed much closer to the traditional goal of philology than Malinowski imagined.

\section{NOTES}

\footnotetext{
* The research on which this article is based was funded by the Department of Research, Universities and Information Society, Generalitat de Catalunya, and the Spanish Ministry of Science and Technology, Research Fund BFF2003-02954. I benefited from a visiting scholar stay at the University of California, Berkeley (spring-summer 2003). I am indebted to two anonymous reviewers who helped to imprive this article. Particular thanks go to Jane McGary, who patiently helped in editing the manuscript and making it a more readable text.

${ }^{1}$ See Dalby's discussion (2003:219-227). Whichever "definition" you agree on, it is even possible to talk about "the after-life of languages" (Dalby 2003:227 ff.) in reference to "dead" language features surviving in living languages.
} 
2 This is a particularly sensitive point in medieval Catalan literary scholarship, since, unlike with French or Spanish epics, no Catalan heroic songs have been preserved as such in manuscript. Thus, the only traces of Catalan epics are allegedly verse-like fragments in chronicle prose. Given the importance that "making a heroic past" had in the birth of modern nations in the 19th century, i.e. in "making the present," to exhibit ancient heroic songs alongside lyric poetry turned out to be of great importance. In the absence of direct evidence, Catalan scholars emphasized indirect evidence from the chronicles. Verse-into-prose conversion is well known in French and Spanish literatures, but in both cases the evidence is direct: heroic poems and their occasional conversion into chronicle prose may be checked against extant manuscripts.

${ }^{3}$ Here I maintain the medieval Catalan spelling. The difference from the modern orthographic form is in the first part of the title: Llibre dels fets del rei En Jaume. This title is commonly used.

${ }^{4}$ This is the oldest surviving copy, held at the University Library, Barcelona. A facsimile was published by the University of Barcelona (Riquer 1971). The monastery of Poblet also keeps King James's mortal remains.

${ }^{5}$ Jaume I, or James I, was one of the most important Catalan kings in the Middle Ages. He conquered the Balearic Isles and the kingdoms of Valencia and Murcia from the Muslims, hence his honorific epithet. During his life the king of Aragon and count of Barcelona dominated an extended zone of the eastern Iberian Peninsula and a part of the Occitan country in southern France.

${ }^{6} \mathrm{I}$ do not enter into the specifics of the controversial issue around the authorship of the Book. See a brief summary of it in Pujol 2001, with reference to different authors' views.

${ }^{7}$ From time to time first person singular leaks out. This has been offered as evidence for the king's authorship.

${ }^{8}$ My translation. Original text: "El rey faze un libro, non porquél el escriva con sus manos, mas porque compone las razones dél, e las emienda e yegua e endereça, e muestra la manera de cómo se deven fazer, e desí escrívelas qui él manda, pero dezimos por esta razón que el rey faze el libro" (quoted from Riquer 1964:399). In contrast to James, Alfonso wrote on distant events. His "history" or chronicle has not the flesh-and-blood flavor of James's.

${ }^{9}$ On the way literary works were diffused and transmitted in the European Middle Ages, see Auerbach 1965. The thirteenth century represents a turning point in the circulation of manuscripts among European elites. However, literacy at the time must be understood as a matter of degree from the ability to recognize letters, to sign, or to recognize certain formulae (e.g. in notarial documents) up to real mastery of the art of reading. Moreover, this new "market of manuscripts" did not necessarily imply the emergence of silent reading as we understand it.

${ }^{10}$ Original text: "E, per tal que sàpien aquels qui aquest libre VEURAN cantes partides ha en Maylorques..." (72:1-2). "E, per tal que sàpien aquels qui HOIRAN aquest libre que cara cosa fo d'armes ço que feyt fo en Maylorques..." (69:49-51).

${ }^{11}$ Cost-benefits: King James grants an investment:revenue ratio of 1:10. Military strategy: It is better to wage war against a common enemy in an alien land than to wait to fight this enemy alone in one's homeland.

12 Insofar as evidence and knowledge pertain to the realm of cognition, this chain of evidence dream, confession, public verbal report, written record - whether true or untrue, may be construed as a series of mental spaces (Fauconnier 1994) including DREAM, BELIEF, REPORT, REALITY, which get conceptually blended into a complex integration network, in the terms of Fauconnier \& Turner 2002. I will not pursue this line of inquiry here. My concern is with the social and verbal dimension of facts.

${ }^{13}$ Burns 1978 points out the episode of the friar's dream as one of the only two "miracles" contained in James's narrative. This is to be highlighted in an age that was fond of wonders. Both cases, Burns notes, are reported "cautiously, and at second hand." An exception to this caution should be made, as we shall see, for James's providential interpretation of his deeds.

14 I follow Bruguera's 1991 edition of the Llibre dels Fets for the original Catalan text. Riquer's 1971 facsimile edition of the manuscript from Poblet may also be consulted. The English texts are taken from Smith \& Buffery's English translation, which was unpublished at the time I wrote: The Book of deeds of James I of Aragon (Smith \& Buffery 2003). I thank the translators for making these passages accessible to me.

15 As to proper names, I include in the text the choices the translators made between English and Romance forms (which occasionally reflect varying points of view) for the sake of consistency, coherence, and the reader's convenience. Obviously, the original texts in notes maintain the original form. 
${ }^{16}$ Bernat Guillem de Montpeller was King James's uncle and counselor. He served him loyally and was holding el Puig de Santa Maria at the time of his death, a key position in the southern frontier near Valencia, in the campaign for the conquest of the town. His death, then, posed a political and military issue, which is in fact the point raised by Don Ferdinand. Bernat Guillem also was known as Bernat Guillem d'Entença after the Catalan lineage of his wife. This is actually the name he receives in the Book.

${ }^{17}$ Original text: "E vengren tots trists denant nós, e dixeren tots los richs hòmens a don Fferrando que $\cdot n s$ mostràs la paraula e que $\cdot n s$ dixés la mort de Don Bernat Guillem. E nós coneguem en les cares d'éls que àvols noves havien hoüdes... . e puys Don Fferrando començà la paraula per él e per los altres e dix-nos axí: 'Seyor, totes les coses del món ha feites nostre Seyor e les desfà quant a ell plau. Ara nós som tenguts a vós de tota re que vostre prou sia, e plauria'ns molt; e de tot embarch que a vós vingués nos pesaria. Perquè havem unes noves hoüdes en què vós poríets menyscabar, si tost no y preníets conseyl. E les noves nos pesen molt, per él, qui ho valia, e per vós: fem-vos saber que Don Bernat Guillem d'Entença és mort, e açò sabem nós per cert. E per ço quan él tenia de vós tan gran cosa e tan honrada e en frontera, mester és que y prengats conseyl" "(231: 7-23).

${ }^{18}$ See Argenter 2004 for discussion of these issues related to the recourse to scriptural, homiletic or folk wisdom quotations in the construction of discourse, as well as for issues related to codeswitching. Contrary to the general approach of those who have dealt with this topic in the Book, codeswitching is not restricted to language alternation. Indeed, the latter does not accompany the former in this case.

19 The whole discourse is an example of a figure known as "suspension." This has a grammatical correlate in the use of "cataphoric" (or anticipated anaphoric) pronominal reference, which is preserved in the English translation: "And we are greatly saddened by the news, both for HIM, who was so worthy, and for you: for we have to inform you that DON BERNAT GUILLEM D'ENTENÇA is dead ..." (Cat. "E les noves nos pesen molt, per EL qui ho valia, e per vós: fem-vos saber que DON BERNAT GUILLEM D'ENTENÇA és mort.”)

${ }^{20}$ Original text: “E, nós, que havíem estat en Saragoça bé per.VIII. dies o per més, vench-nos missatge que Don Bernat Guillem d'Entença era mort” (231:1-2).

${ }^{21}$ The character's suspensive discourse strategy, noted above, ostensibly contrasts with the narrator's anticipatory technique noted here. This contrast might be understood as a switch in point of view from on-line discursive performance to a posteriori narrative.

${ }^{22}$ For the concepts "felicity conditions" of speech acts, "performative" utterance, "perlocutionary force," see Austin 1966.

${ }^{23}$ Original text: "E acordaren-se; $e$, quant foren tornats denant nós parlà Don Ferrando per tots los altres ço que havien acordat e dix: "Senyor, en esta cosa que vós nos havets dita veem gran enbarch per aquestes raons que nós vos direm: car no seria mester que vós comensàssets nulla res, si no la acabàvets bé, e en tota la ost no ha de menjar per.v. dies. E València no és vostra, ans la tenen los sarrahins." (195:3-9).

${ }^{24}$ Bauman's terms refer to participants in so-called mediational routines. Though I distinguish "delegated" from "mediated discourse" here, these terms are general enough to describe more complex forms of participant structure than a dyadic view of it does.

25 There are examples of both in the Book.

${ }^{26}$ E dix-nos l'arquibisbe les paraules que havia haüdes ab ell; e nós dixem-los que no devien anar així, entre nós e ell, que ell, qui era arquibisbe, e $\cdot$ lls bisbes $e \cdot l l s$ richs hòmens e $\cdot$ lls ciutadans que y eren, que li devien dir: “ ¿Vós per què estats mal ab vostre pare? Car diu-vos que, si tort vos té, que us ho adobarà a coneguda de vós. E, si vós açó no volets fer, fem-vos saber que perdrets a nós e tot lo regne; e irem contra vós, així con contra aquel qui és rebel a som pare”. ¿E con vos partrets vosaltres d'aquí que sots justats, que no $\cdot n$ s façats negun fruyt en tan gran mal con aquest és de nós e d'ell? Cant trobarets nuyl hom al camí, e us dirà con havets jaquit lo rey e son fill en guerra ni en mal, anar-vos n'ets con a malastruchs" (518: 5-17).

${ }^{27}$ See Bauman 2004:128-58 for the terms "source," "target," "source dialogue," and "target dialogue," as well as for an analysis of mediated discourse.

${ }^{28} E$, quan foren là, dixeren a l'arquibisbe que dixés la rahó per tots, e ell dix que no la diria. E dixeren-ho al bisbe de Barcelona e a altres richs hòmens, que ho dixessen, e anch negú no ho volch dir. E dixeren a $\cdot N$ Johan Gil que u dixés ell per tots; e dix En Johan Gil: “ ¿E con diré jo la paraula, estan aquí arquibisbe e bisbes e richs hòmens? ¿E con ho faré jo?” E dixeren tots que volien que ell ho dixés. E levà les mans a nostre Senyor e dix: "Jo graesch a Déu quan aquí comanen a mi la 
paraula; e plàcia a Déu que jo la pusca dir en tal manera que sia a honor del rey e a bé de l'infant". E dix la paraula, mas no tan complidament ne tan fort con nós los havíem dit. E puys tornaren a nós e dixeren que no u podien acabar. E dixeren-nos ço que volia fer l'infant, que faera cosa qui fóra a escarn de nós; e nós no u volguem creure. E·lls richs hòmens dixeren que, pus aquí no podien res acabar e que havien despès ço que havien, que s s n'irien. E nós dixem: "Ara anats-vos-en en mala ventura, que nós acabarem ço que demanam, bé, meyns de vosaltres". E així anaren-se'n (519).

${ }^{29}$ Above we have seen the king's reproach to his messengers in the story.

${ }^{30}$ Original text: "Ab aytant nós nos levam en peus e volguem-nos tolre lo capel del cap; e dix-nos l'apostoli que no u faéssem e que siguéssem e que tornàssem lo capel en la testa; e açò mateix nos dixeren los cardenals tots a.I. vots. E, quan fom asseguts, dixem-li que ell nos ha enviat missatge e prechs que nós que venguéssem al dia del consili; e aenant envià'ns.I. prehicador, per nom frare Pere d'Alcanà, lo qual nos havia aduyta carta que nós lo creeguéssem de ço que ell nos diria de la seua part; e nós dixem-li que .I. ${ }^{a}$ paraula li retreýem que diu nostre Senyor en l'Avangeli: Gloriam meam alteri non dabo. 'E per açò dich jo esta paraula: que, puys jo volia venir a vós, e vós m'aviets enviat missatge, lo meu cor no volia a altre descobrir sinó a vós, car no era rá que la mia bona voluntat dixés jo a missatge vostre, sinó a la vostra pressona e denant aquels que vós volríets. $E$ trobam per les Profetes, ço és, per Isaías, que a la festa de dona sancta Maria, cant trasch nostre Senyor al temple offerí, que dix: Lumen ad revelationem gencium, que diu: 'La lum és revelada a totes les gents'. E açò és ver, que quan ell nasch, e nostra dona sancta Maria l'havia offert al temple, que $\cdot$ l fiyl de Déu era revelat a les gents. Per què ara podem retraure que d'aquest vostre concili, que serà bo e sant, aquesta paraula, en semblança d'aquela: que ço que $\cdot l s$ altres apostolis no faeren ni compliren, en cobrar lo sant Sepulcre d'Oltramar, en què Déus volch morir per nós e ésser sebulit en aquela terra, que per vostra paraula e per vostra obra, que farets ab los clergues e ab los nobles d'aquest món, que ara venga a acabament; e que aquel lum qui no poch venir a acabament tro a hora d'ara, vinga en acabament en vostre temps e que per vós sia encès. E jo só vengut ací per.II. coses que vós m'enviàs a demanar, e la terça és mia: la primera és que m'enviàs a demanar que us donàs conseyl; e la segona, ajuda. E só vengut aquí que us do conseyl, lo meylor que jo poré ne sabré ni Déus me metrà en ma pensa; e que jo vos ajut. La terça és mia: que us anagaré los altres que no han cor de servir nostre Senyor; e dir-hi he tant jo e y faré, que per açò s'auran a anagar'. E d'aquesta paraula preseren-se a riure l'apostoli e $\cdot$ lls cardenals, per ço con ho haviem tan bé dit. $E$ en tant lexam-los aquí molt pagats de nós, e gra[. . ]yren-nos molt la paraula que nós los havíem dita. E puys anam-nos-ne a nostra albergada." (527)

${ }^{31}$ This does not imply that knowledge of biblical sources was direct at that time - it could be mediated by homiletics or liturgy.

32 This feature was common also in clerical discourses through the Middle Age: triads were commonplace in preaching and writing. Indeed, this stemmed from biblical literature.

${ }^{33}$ Note, then, that both scriptural quotations have their source in close lines in the same book.

${ }^{34}$ All these inexactitudes, which have been noted frequently by historians and philological critics (Soldevila 1971a, Bruguera 1991: I, Pujol 2001), are irrelevant from the point of view of the management of discursive resources or ethno-pragmatics. Or else, they are irrelevant to their pragmatic effectiveness. The scriptural source, the occasional metapragmatic assertion of responsibility for it, either right or wrong, the Catalan/Latin codeswitching and its oral/written source language contrast, are much more relevant features for quotations to be invested with social effectiveness.

${ }^{35}$ Pálsson $(1995: 8,177)$ makes a case against "textual" anthropological and historical analyses, based on the idea of "culture-as-text" and on inquiry into (inter)textual relationships, and advocates for a "living discourse" analysis, highlighting discourse practices, hence agency. I am sympathetic with a "living discourse" and agency-oriented approach, but I understand this type of (inter)textuality to be controlled by agents, thus to be a type of discourse practice. We are not dealing with only textual relations or philological sources discovered by the analyst, but with the living management of "texts" and verbal resources by a living actor as a way to invest discourse with authority or to present oneself as invested with authority - in fact, as a voice that has to be listened to.

${ }^{36}$ This preface was probably written later, after James's death.

${ }^{37}$ One of the greatest Catalan writers in the Middle Ages was Ramon Llull, who wrote poetry, romance prose, scientific and philosophical works, and pedagogic and apologetic literature in Arabic, Latin, and Catalan. Llull was famous for his teaching in universities all over Europe, his trips to Muslim and other countries, and his knowledge of both Islamic and Christian theology. He displayed the intellectual controversy between the two systems in order rationally to convert Muslims to the 
Christian faith. Centuries later public debates between Muslim and Christian authors still were held to argue which was the true religion.

${ }^{38}$ This policy, however, was contradicted by his last will, by which he divided his territories and possessions among his children.

\section{REFERENCES}

Anderson, B. R. O'G. (1972). The idea of power in Javanese culture. In Culture and politics in Indonesia, ed. C. Holt. Ithaca: Cornell University Press. 1-69.

Argenter, Joan A. (2001). Code-switching and dialogism: Verbal practices among Catalan Jews in the Middle Ages. Language in Society 30:377-402.

(2004). L'alternança de llengües i la commutació de codi en la Crònica de Jaume I. Estudis Romànics 26: 109-27.

(2005a). Did our ancestors code-switch? Inferring from written records. In James Cohen et al. (eds.), ISB4: Proceedings of the 4th International Symposium on Bilingualism, pp 84-93. Somerville, MA: Cascadilla.

(2005b). Oratory, power and authority in medieval Catalan society: Code-switching and the construction of political discourse. Paper presented at the colloquium "A historical ethnographic approach to bilingualism, verbal practices and linguistic ideologies," Fifth International Symposium on Bilingualism, Barcelona, March 20-23, 2005.

(1970 [1967]). Il simbolismo tipologico nella letteratura medievale. In his S. Francesco,

Dante, Vico. Bari: De Donato.

(1974 [1944]). Figura. In his Studi su Dante. Milan: Feltrinelli.

(2003 [1953]). Mimesis: The representation of reality in Western literature. Princeton: Princeton University Press.

Austin, John (1966). How to do things with words. Oxford: Oxford University Press.

Badia, Antoni M. (1987). Coherència i arbitrarietat de la substitució lingüística dins la Crònica de Jaume I. Barcelona: Institut d'Estudis Catalans.

Bakhtin, Mikhail M. (1981). The dialogical imagination. Edited by M. Holquist. Austin: University of Texas Press.

Batlle, Carme (1988). Historia de Catalunya III. Pierre Vilar, general editor. Barcelona: Edicions 62. Bauman, Richard (2004). A world of others'words. Oxford: Blackwell.

\& Briggs, Charles. L. (1990). Poetics and performance as critical perspectives on language and social life. Annual Review of Anthropology 19:59-88.

$2: 131-72$. (1992). Genre, intertextuality and social power. Journal of Linguistic Anthropology \& Sherzer, Joel (1974) (eds.). Explorations in the ethnography of speaking. Cambridge: Cambridge University Press.

Bloch, Maurice (1975) (ed.). Political language and oratory in traditional society. New York: Academic Press.

Bruguera, Jordi (1991) (ed.). Llibre dels fets del rei En Jaume. (Els nostres clàssics, Series B, 1011.) 2 vols. Barcelona: Barcino.

Burns, Robert I. (1978). The spiritual life of James the Conqueror, king of Arago-Catalonia, 12081276. Portrait and self-portrait. In his Moors and Crusaders in Mediterranean Spain. London: Variorum Reprints.

Dalby, Andrew (2003). Language in danger: The loss of linguistic diversity and the threat to our future. New York: Columbia University Press.

Duranti, Alessandro (1981). The Samoan fono: A sociolinguistic study. (Pacific Linguistic Monographs, Series B, vol. 80). Canberra: Australian National University, Department of Linguistics. (1993). Intention, self, and responsibility: An essay in Samoan ethnopragmatics. In Hill \& Irvine, $1993 \mathrm{~b}, 24-47$.

Errington, J. Joseph (1998). Shifting languages: interactionad identity in Javanese Indonesia. Cambridge: Cambridge University Press.

Fauconnier, Gilles (1985 [1994]). Mental spaces: Aspects of meaning construction in natural languages. Cambridge: Cambridge University Press. 
\& Turner, Mark (2002). The way we think: Conceptual blending and the mind's hidden complexities. New York: Basic Books.

Friedrich, Paul (1986). The poetry of language in the politics of dreams. In his The language parallax. Austin, Texas: University of Texas Press.

Goffman, Erving (1981). Forms of talk. Philadelphia: University of Pennsylvania Press.

Hill, Jane H., \& Irvine, Judith I. (1993a). Introduction. In Hill \& Irvine 1993b, 1-23.

(1993b) (eds.). Responsibility and evidence in oral discourse. Cambridge: Cambridge University Press.

Irvine, Judith I. (1974). Strategies of status and manipulation in the Wolof greeting. In Bauman \& Sherzer, 167-99.

Jakobson, Roman (1957 [1971]). Shifters, verbal categories, and the Russian verb. In his Selected Writings, 2:130-47. The Hague: Mouton.

Lucy, John A. (1993) (ed.). Reflexive language: Reported speech and metapragmatics. Cambridge: Cambridge University Press.

Malinowski, Bronislaw (1923). The problem of meaning in primitive languages. In Charles K. Ogden \& Ivor A. Richards (eds.), The meaning of meaning, Supplement I, 296-336. New York: Harcourt, Brace, \& World.

Pálsson, Gísli (1995). The textual life of savants: Ethnography, Iceland, and the linguistic turn. Chur: Harwood Academic.

Pujol, Josep M. (2001). ¿Cultura eclesiàstica o competència retòrica? El llatí, la Bíblia i el Rei En Jaume. Estudis Romànics 23:147-72.

Riquer, Martí de (1964). Història de la literatura catalana I. Barcelona: Ariel.

(1971) (ed.). Libre dels feyts del rey En Jacme. Edición facsímil del manuscrito de Poblet (1343) conservado en la Biblioteca Universitaria de Barcelona. Barcelona: Universidad de Barcelona.

Sherzer, Joel (1983). Kuna ways of speaking: An ethnographic perspective. Austin: University of Texas Press.

Silverstein, Michael (1996a). Indexical order and the dialectics of sociolinguistic life. In R. Ide et al. (eds.) Third Annual Symposium on Language and Society - Austin, 266-95. Austin: Department of Linguistics, University of Texas. , \& Urban, Greg (1996a). The natural history of discourse. In Silverstein \& Urban, 1-17. (1996b) (eds.). Natural histories of discourse. Chicago: University of Chicago Press.

Smith, Damian J., \& Buffery, Helena (2003) (trans.). The Book of deeds of James I of Aragon: A translation of medieval Catalan Llibre dels fets. Burlington, VT: Ashgate.

Soldevila, Ferran (1971a). Prefaci al Llibre dels feits del Rei En Jaume o Crònica de Jaume I. In Soldevila (ed.), 7-64.

(1971b) (ed.). Les quatre grans cròniques. Barcelona: Selecta.

Urban, Greg (1996). Entextualization, replication, and power. In Silverstein \& Urban (eds.), 21-44. Vicens Vives, Jaume (1954). Notícia de Catalunya. Barcelona: Destino.

Vilar, Pierre (1988). Pròleg. In Batlle, 9-14.

Watkins, Calvert (1981). Aspects of Indo-European poetics. Indo-European Studies 4:764-99.

Yankah, Kwesi (1995). Speaking for the chief: Okeyame and the politics of Akan royal oratory. Bloomington: Indiana University Press.

(Received 8 January 2004; accepted 12 January 2005; final revision received 30 May 2005) 